June 12 (red, adult male) and July 3 (adult female). Throughout June and July, two red and one yellow male as well as two females were regular visitors. The yellow variant male was first seen on June 14. From July 26 to 29 , we had six females (this number could possibly include immatures). An orange variant male was seen on August 9.

Throughout the beginning of August, up to six finches were seen at one time, with young being fed. On August 20, eight House Finches visited the feeders, including five females/immatures, one red adult, two pink immatures and one yellow variant male. On August 27, the number increased to eight females/ immatures and two red, one pink and one yellow male. House Finches were feeding in early September 2000 in mixed flocks with House Sparrows. We watched an immature House Sparrow begging food from an adult female House Finch that moved away and did not feed it.

On September 2, there were fourteen females/immatures plus four bright red males. Over the next few weeks, the female/immature numbers stayed between eight and ten, and the males, up to eight: four bright red, two pink, one yellow and one orange. Six to eight House Finches visited our feeders until the end of October.

On November 5 , the weather turned cold and snow began to blow around 2:00 a.m., continuing through much of the day. Along with a variety of birds at the feeders, we had seven female House Finches, and seven red/pink, one orange and one yellow male. The same numbers were here again on November 6 . The House Finches were very aggressive towards the $200+$ House Sparrows that push their way to the feeders.

The different color variants at our feeders is certainly a nice change from the huge flocks of House Sparrows that are attracted to our feeding stations. We are pleased that the House Finches seem to have nested successfully here. We had from four to fourteen House Finches visiting the feeders right through to the end of March 2001. With the arrival of spring, their wonderful song is a delight through the open kitchen window. It will be interesting to see if the numbers continue to grow throughout the summer.

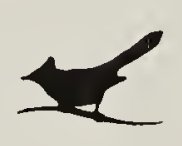

\section{OBSERVATIONS FROM BANDING HOUSE FINCHES IN THE FALL OF 1995 AT REGINA, SK}

DALE AND PAULE HJERTAAS, 15 OIson Place, Regina, SK S4S 2J6.

The House Finch is native to western North America, where it occupies habitats from open desert to urban areas in southern British Columbia east to
Montana and south to southern Mexico. In 1940, a small group of House Finches taken to Long Island, New York for the cage bird trade, were released locally. 
They became established and spread north, south and west through most of the eastern United States and southern Ontario and Quebec.?

House Finches were first reported in Saskatchewan in 1959 with three subsequent reports in the 1970 s. These early sightings are thought to have been strays from the western population. ${ }^{2}$ The next sightings were several birds seen in the late 1980s and these could have come either from the east or the west. Saskatchewan numbers were still low at the end of the 1980s, and by October 1990, only 11 House Finches had been reported in Saskatchewan. ${ }^{2,8}$

By 1995, the House Finch was clearly increasing in Saskatchewan, but numbers still appeared to be small. The 1994 Christmas Bird Counts recorded this species in three locations - Regina reported 14, Weyburn 16 and Whitewood 4. House Finches were observed during the 1995 Christmas Bird Count period at Saskatoon and Fort Qu'Appelle. ${ }^{5}$

We first observed a House Finch, a lone male, in our yard at 15 Olson Place, Regina on 17 May 1994. The next observation was in November 1994 when we recorded 12 House Finches on both the 11th and 20th. Our next recorded sighting was of 14 birds observed on the Regina Christmas Bird Count at our feeder on 26 December, 1994. Ten were still present 10 January 1995 but through the rest of the winter we recorded House Finches only on 23 February (4) .

We started seeing them again on 28 April 1995, and then saw one or two, often a pair, throughout the spring. The largest numbers observed in spring 1995 were four on 17 May and 22 May, and 11 males on 20 May. A male was recorded singing on 13 and 19 May and our first confirmation of local breeding was on 26 May when a juvenile, still showing tufts of down, visited our feeder. Thereafter, we observed House Finches occasionally, never more than a family group. The only spring banding that we did in 1994 was on 22 and 23 May when we banded one and seven birds respectively.

In the fall of 1995, the largest flocks were 10 on 15 October, 11 on 6 November, and 9 on 9 November. One to five birds were seen on 5 dates between 8 November and 13 December, after which they apparently left.

Except for the one group of 11 males in May, 1995, all these observations were consistent with our belief that a small group of no more than 2 or 3 pairs with young were resident in our area. Our banding, however, showed a very different picture.

Our banding station is in our back yard at 15 Olson Place, Regina. This part of Regina was developed in the early 1960s; the trees were almost 40 years old in 1995. Large spruce and poplar, Green Ash and mountain-ash as well various shrubs provide cover. Bird feeders and sunflower seeds scattered on the ground help attract birds.

Two mist nets were set up along the lawn edge to capture birds as they moved from feeders to trees. Several single bird traps also were used, although most captures were in mist nets. Nets were only open when one of us was available to handle the birds. Captured birds were removed at least every 30 minutes, bagged, weighed, measured, banded and then released.

In the fall of 1995 , we began banding operations on 29 August and continued until 6 November. We captured the first House Finch on 23 September. Table 1 
Table 1. Number of House Finches captured and number of days nets were open by week at 15 Olson Place, Regina in fall 1995

\begin{tabular}{|l|c|c|}
\hline Week Beginning & \# Days nets open & Finches Captured \\
\hline 27 August & 4 & 0 \\
\hline 3 September & 3 & 0 \\
\hline 10 September & 4 & 0 \\
\hline 17 September & 4 & 1 \\
\hline 24 September & 6 & 1 \\
\hline 1 October & 7 & 5 \\
\hline 8 October & 4 & 19 \\
\hline 15 October & 7 & 37 \\
\hline 22 October & 4 & 16 \\
\hline 29 October & 3 & 5 \\
\hline 5 November & 1 & 1 \\
\hline
\end{tabular}

shows the captures (and 3 recaptures) for this period, week by week, through 6 November when we banded the 81 st House Finch of the autumn. One additional bird escaped before banding, so we probably handled 82 individuals. Since none of these was a recapture of one of the 8 banded in the spring, we handled a total of 90 House Finches in 1995 , far more than the one or two families and several transients we had thought were present in our area.

It is doubtful that we captured every bird that visited our yard; indeed it was rare for more than $25 \%$ of the House Finches observed in our yard at any one time to be banded. We also doubt that all House Finches in Regina chose to visit our yard. The total population in or passing through Regina in fall of 1995 may therefore have been significantly larger than the 81 birds we banded.
Unfortunately, our skill at aging and sexing these birds was still developing. As a result, the majority (52) were classed as of unknown age. Twenty were identified as young of the year and only 13 as in their second year or older. There were three recaptures: one banded 11 October and recaptured 19 October, and two banded 15 October and recaptured 24 October. All were of undetermined age and sex.

Besides the large number of birds captured, the other striking feature of these data is the dates of capture. If all of these finches had been resident, we would have expected a steady catch rate throughout the fall with a significant number of recaptures. Instead the number captured showed the pattern typical of a migrating population, such as that shown by the juncos or Whitethroated Sparrows we also band. We 
banded one House Finch on 23 September, almost a month after we began banding operations. Table 1 shows that numbers gradually increased to peak in the week of 15 October, then declined until we quit banding due to colder weather on 6 November. This pattern is suggestive of migration.

House Finches in the original western part of their range show little migratory behaviour ${ }^{1,7}$. However, this species has developed migratory behaviour since becoming established in the east ${ }^{7}$ and although some eastern birds do remain in breeding areas all winter, the majority migrate. Migration distance has varied with study area, but was short in each of two studies, $112 \mathrm{~km}$ along the eastern seaboard and an average of $345 \mathrm{~km}$ in the American Midwest 3,4 .

In conclusion, the banding data clearly show that the House Finch population at Regina was increasing rapidly by fall of 1995 and show that this population was mobile. This mobility may be migratory, as reported in eastern North America, with some birds resident, or the movement we observed may simply be movement within the city. Wintering areas of these birds, if they migrate, are unknown. Perhaps future band recoveries will answer this question.

1. Aldrich, John W. \& John S. Weske. 1978. Origin and evolution of the
Eastern House Finch population. Auk 95:528 - 536 .

2. Bancroft, Jean \& Robert J. Parsons. 1991. Range expansion of the House Finch into the Prairie Provinces. Blue Jay 49 : 128-136.

3. Belthroff, James R. \& Sydney A. Gauthreaux Jr., 1991. Partial migration and differential winter distribution of House Finches in the eastern United States. Condor 93: 374-382.

4. Hamilton, Thomas R. 1991. Seasonal movement of House Finches in the midwest. North American Bird Bander 16(4): 119-122.

5. Harris, Wayne C. 1995. 53rd Annual Saskatchewan Christmas Bird Count 1994. Blue Jay 53(2):71-91.

6. Harris, Wayne C. 1996. 54th Annual Saskatchewan Christmas Bird Count 1995. Blue Jay 54(1):7-30.

7. Hill, Geoffrey E. 1993. House Finch (Carpodacus mexicanus). In The Birds of North America , \#46 (A. Poole \& F. Gill, Eds.). Philadelphia: The Academy of Natural Sciences; Washington, D.C.; The American Ornithologists Union.

8. Kreba, Robert 1990. Field Checklist of Saskatchewan Birds. Saskatchewan Natural History Society in cooperation with Saskatchewan Museum of Natural History \& Canadian Wildlife Service.

"A flock of lice... A knot of toads... A murmuration of starlings... A tiding of magpies... A paddling of ducks... A spring of teal... A peep of chickens." 
GREAT GRAY OWLS by Tim Garton

The owls in the snow were four different owls. I was fortunate enough to watch a getting prey. I took the photographs during the months of January, February a that I have ever seen was located between Powerview and Manigotogan, Manitot Highway 302.

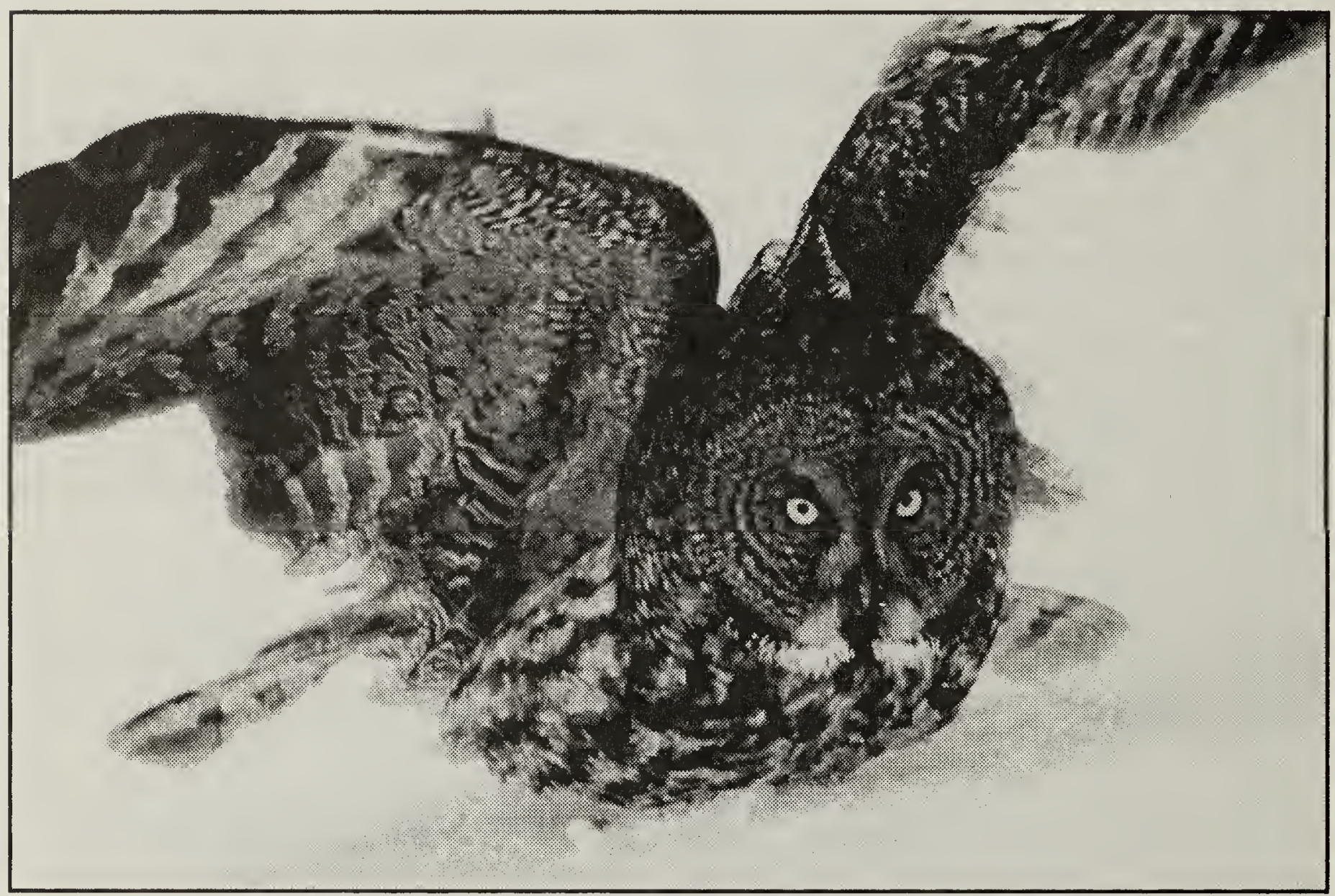

Landing on snow - the moment of impact

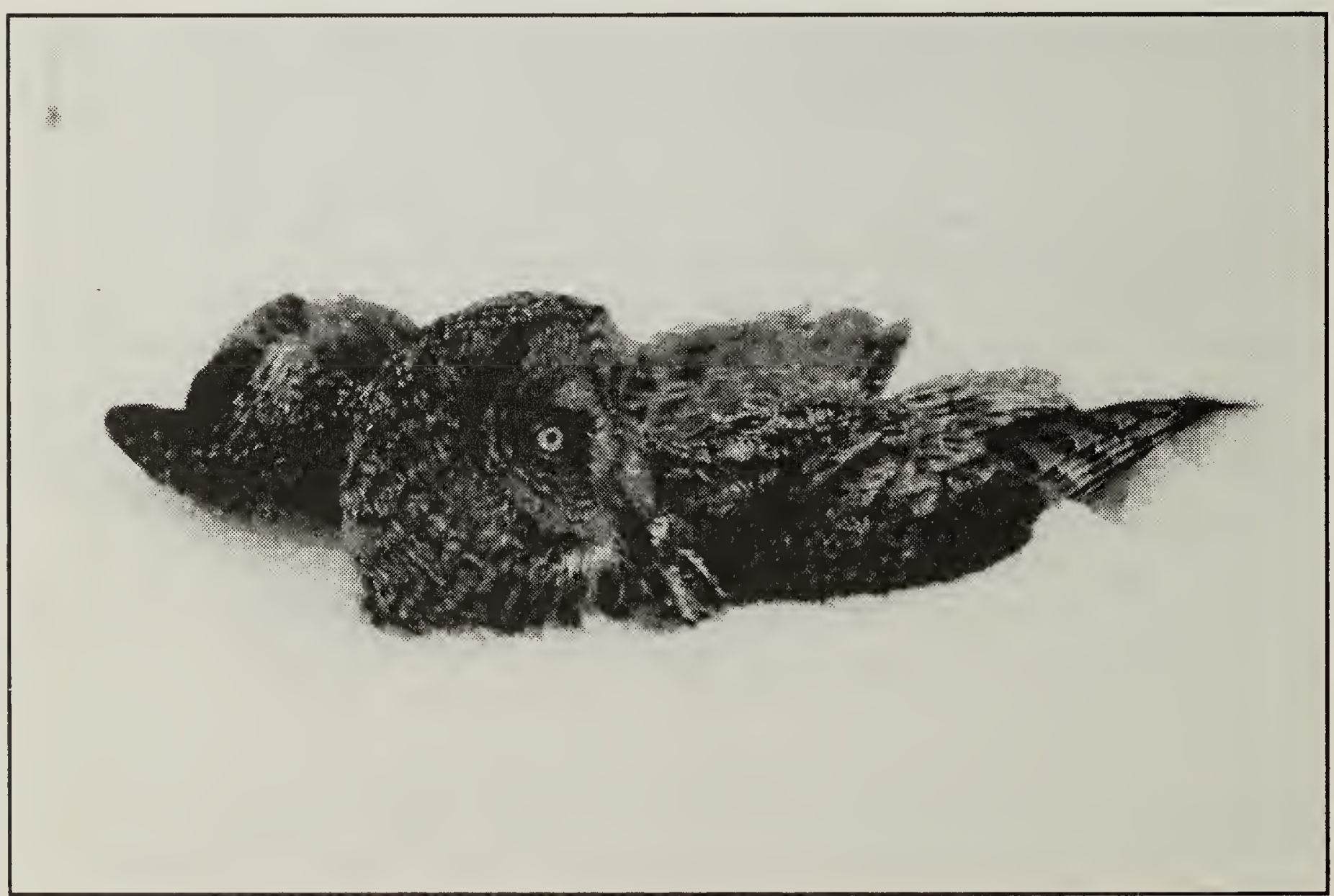

This owl landed on the snow, wings spread out, and flew away with a vole afterwards. 
it for them to fly down from their perches and plunge into the snow in hopes of irch of 2001, $190 \mathrm{~km}$ northeast of Winnipeg. The heaviest concentration of owls January 20, 2001, I saw 44 owls from Highway 59 northeast to Manigotogan on

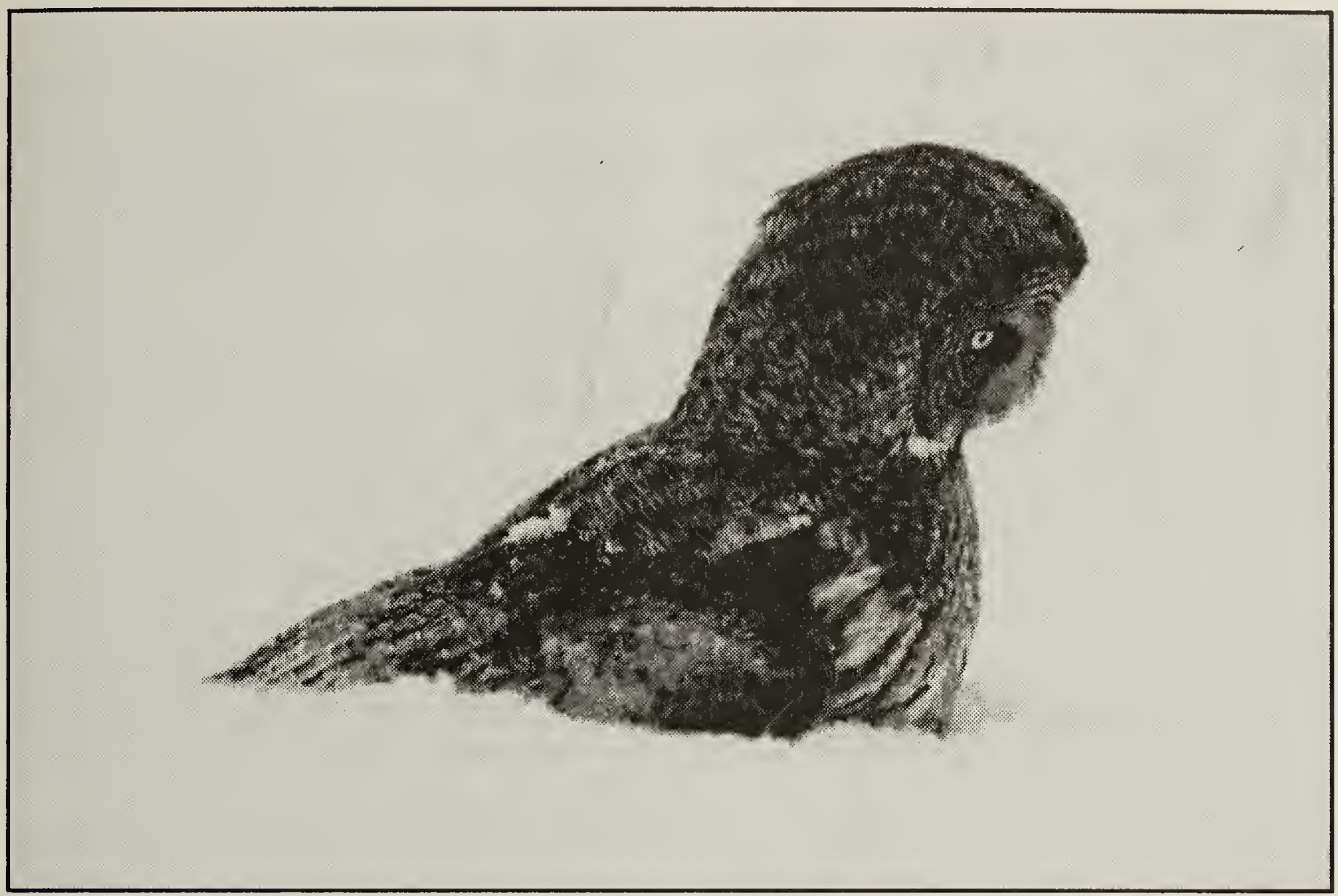

Listening and peering down into the snow

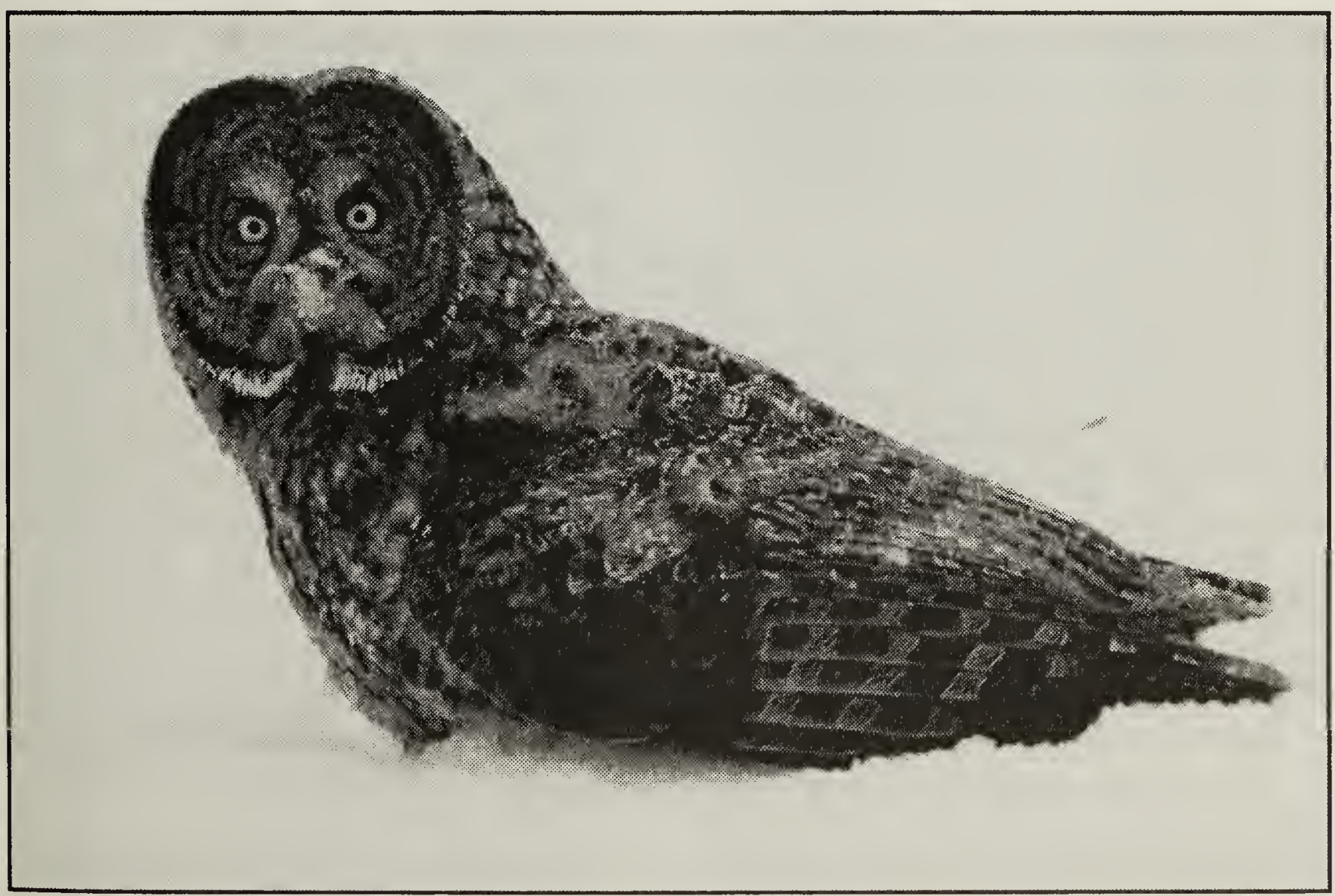

After putting its bill into the snow, this owl turned to face the camera. 